\title{
WPŁYW ŚWIATOWYCH CEN ROPY NAFTOWEJ NA WARTOŚĆ KAZACHSTAŃSKICH SPÓtEK
}

\author{
Tolkyn Akanayeva ${ }^{*}$, Arnagul Tishtykbayeva**
}

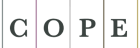

Member since 202

JM15102

\section{cc) creative}

\section{IMPACT OF WORLD OIL PRICES ON THE VALUE OF KAZAKHSTANI COMPANIES}

\begin{abstract}
The article examines the impact of world oil prices on the value of Kazakh companies based on their own calculations. The subject of the analysis is the shares of companies from various sectors of the economy. The purpose of this article is to study the impact of world oil prices on the stock prices of selected companies in Kazakhstan. The results of the study show that the market value of the companies studied is highly dependent on changes in world oil prices on world exchanges.
\end{abstract}

Keywords: Kazakhstan Stock Exchange, company share prices, oil prices.

JEL Class: G120.

\footnotetext{
* Magister nauk ekonomicznych, Katedra Bankowości i Rynków Finansowych, Uniwersytet Ekonomiczny w Katowicach, e-mail: tolkyn.akanayeva@edu.uekat.pl https://orcid.org/0000-0002-8333-0333

** Magister nauk ekonomicznych, Katedra Finansów, Faculty of Economics and Sociology, Uniwersytet Karagandyjski im.E. Bukietowa, e-mail: arnagul0707@mail.ru https://orcid.org/0000-0002-5784-1367
} 


\section{WSTĘP}

Niezależnie od tego, że gospodarka Kazachstanu rozwija się szybko w ciągu ostatnich 20 lat, jej cechą charakterystyczną jest to, że ma orientację surowcową. Głównymi sektorami gospodarki są gałęzie przemysłu energetycznego, skutkiem czego istnieje silna zależność wartości kazachskich spółek od koniunktury na światowych rynkach surowców energetycznych. Czynnik ten negatywnie wpływa na obecny stan rynku akcji i możliwości prognozowania jego rozwoju, co prowadzi do jego niskiej atrakcyjności dla potencjalnych inwestorów krajowych i zagranicznych. Celem tego artykułu jest zbadanie wpływu światowych cen ropy naftowej na notowania akcji wybranych spółek giełdowych w Kazachstanie. Próbę badawczą stanowią akcje 8 największych spółek kazachskich z różnych branż gospodarki. Powodem wyboru tych spółek do badania jest to, że po pierwsze, akcje te są najbardziej płynne na giełdzie; po drugie znalazły na liście KASE (Kazachstan Stock Exchange - KASE) i faktycznie generują $80 \%$ obrotu na giełdzie; po trzecie, jako instrumenty finansowe są popularne wśród inwestorów. Wyniki badań wskazują, że wartość rynkowa zbadanych spólek gełdowych jest silnie zależna od zmiany światowych cen ropy naftowej na giełdach światowych.

\section{CHARAKTERYSTYKA RYNKU PAPIERÓW WARTOŚCIOWYCH W KAZACHSTANIE}

Rynek papierów wartościowych w Kazachstanie ma stosunkowo krótką historię. Rozwój rynku papierów wartościowych w Kazachstanie rozpoczął się na początku lat 90. XX wieku i ma wiele cech specyficznych: po pierwsze, powstaje zgodnie z klasycznymi prawami gospodarki rynkowej, po drugie, uosabia cechy epoki początkowej akumulacji kapitału, po trzecie, odzwierciedla specyfikę Kazachstanu. Na jego tworzenie i funkcjonowanie miało silny wpływ wiele czynników ekonomicznych, politycznych, kadrowych, historycznych i krajowych. Jednak od czasu utworzenia w republice giełdy w kraju wiele zrobiono dla jego rozwoju. Obecnie rynek papierów wartościowych Kazachstanu rozwija się głównie jako: rynek walutowy, rynek bonów skarbowych, rynek akcji i obligacji korporacyjnych, rynek pieniężny, rynek instrumentów pochodnych. Wśród nich najbardziej istotny jest rozwój rynku akcji. Poprzez emisję i rozmieszczenie akcji dokonuje się w Kazachstanie większość mobilizacji oraz alokacji środków finansowych na publicznym rynku papierów wartościowych. W dniu 1 stycznia 2020 roku kapitalizacja rynku akcji wyniosła 17,22 bln. tenge, czyli 26\% PKB, w porównaniu z analogicznym okresem 1 stycznia 2019 r. wzrost wyniósł 11,56\% (wykres 1). 


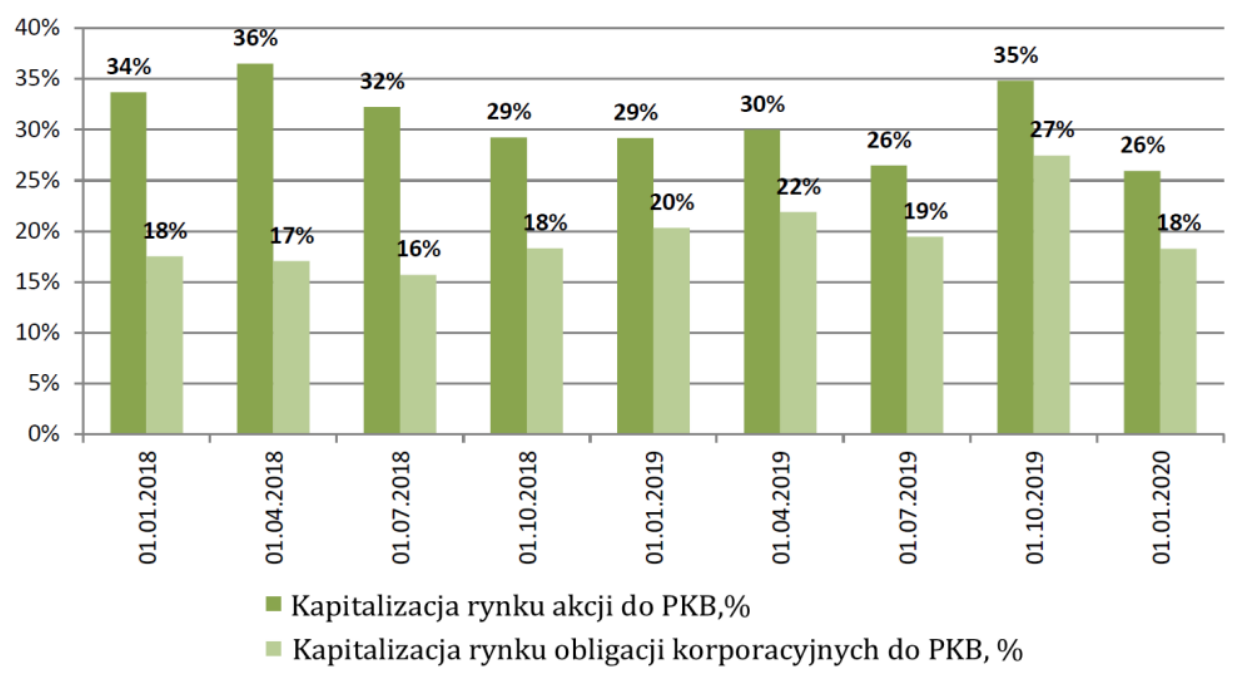

Wykres 1 . Kapitalizacja rynku akcji i obligacji korporacyjnych w stosunku do PKB (\%) Źródło: http://finreg.kz.

Dane z raportu rocznego Giełdy Papierów Wartościowych Kazachstanu świadczą o tym, że w ciągu 2019 roku 122 emitenty 138 razy wyemitowały swoje akcje na giełdzie. Emitenci akcji na giełdzie są reprezentowani przez spółki z sektora energetyki $(49,2 \%)$, finansów (19\%), materiałów (18,7\%), przemysłu (7,5\%), telekomunikacji $(4,7 \%)$ i innych sektorów gospodarki. Jednocześnie w kategorii „Premium” głównej platformy znajdują się akcje 8 spółek, w kategorii „Standard” głównej platformy - akcje 134 spółek, w kategorii „Alternatywna Platforma” akcje 49 spółek. Obecnie w strukturze obrotu akcjami większość obrotów handlowych przypada na osoby fizyczne i prawne niebędące inwestorami instytucjonalnymi, których łączny udział wynosi 7,8\%. Średnia dzienna liczba transakcji w ciągu 2019 r. wynosi 730 transakcje, a średnia dzienna kwota transakcji wynosi 985,12 bln. tenge (Sprawozdanie roczne KASE, 2020). Jak wskazuje wykres, kapitalizacja rynku akcji stale się zmienia. Na aktywność inwestorów w tym segmencie w znacznym stopniu wpływają wstrząsy zewnętrzne i sytuacja gospodarcza w kraju. Zmiany cen ropy naftowej i kursu walutowego niekorzystnie wpływają na chęć i zdolność inwestorów detalicznych do nabywania i zatrzymywania aktywów wyrażonych w walucie krajowej. 


\section{ZMIANA INDEKSU NA RYNKU AKCJI W KAZACHSTANIE}

Głównym wskaźnikiem Giełdy Papierów Wartościowych Kazachstanu jest indeks KASE. Indeks KASE jest cenową, ważoną kapitalizacją rynkową, kompozytowym indeksem kazachskiego rynku akcji. Obliczanie indeksu KASE odbywa się codziennie w czasie rzeczywistym w tenge, co czyni go niezmiennym w stosunku do zmian kursów walut i pozwala odzwierciedlać rzeczywisty stan rynku Kazachstanu. Obejmuje on 8 najbardziej płynnych akcji największych i dynamicznie rozwijających się emitentów Kazachstanu. Działalność gospodarcza, która należy do głównych branż gospodarki reprezentowanych na Giełdzie w Kazachstanie stanowią: SA «Bank CentrKredyt», SA «KazMinerals PLS», SA «Halyk Bank», SA «Kcell», SA «NAK KazAtomProm», SA «KazakhTelekom», SA «KazTrans Oil», SA «KEGOC».

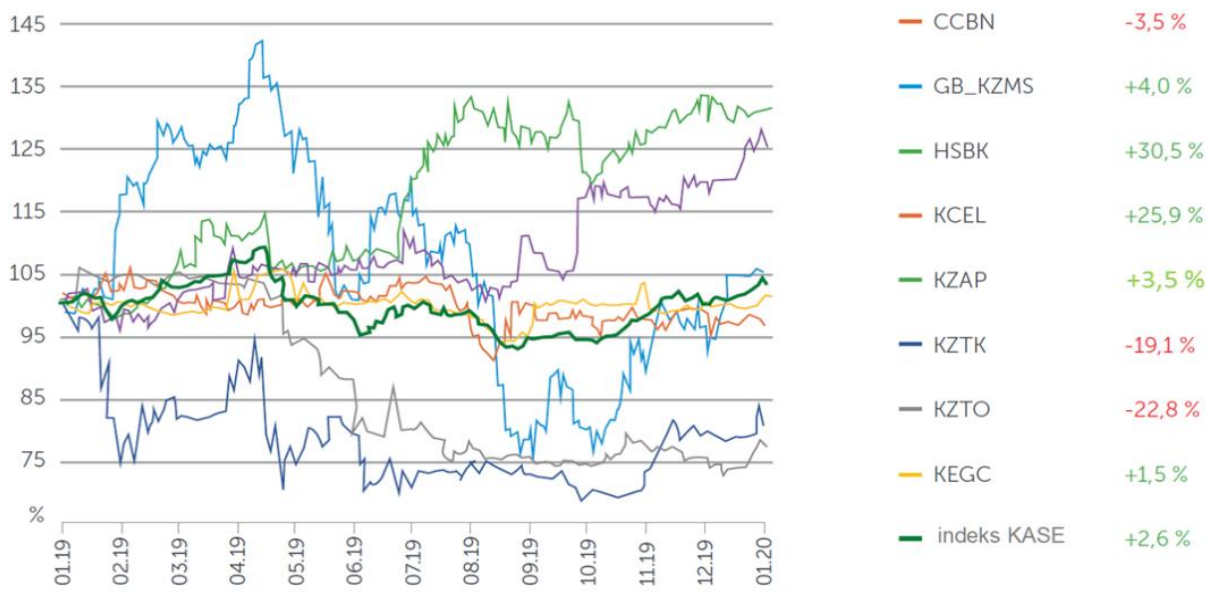

Wykres 2. Dynamika notowań składników indeksu KASE

Źródło: Sprawozdanie roczne KASE (na dzień 01.01.2020).

Na dzień 1 stycznia 2020 r. indeks KASE wyniósł 2 363,79 pkt. Średni dzienny wolumen obrotu wyniósł 827,5 mln tenge, średnia dzienna liczba transakcji - 420, średni wolumen jednej transakcji - 2,0 mln tenge. Łączny wolumen obrotu akcjami indeksowymi wyniósł 108,4 mld tenge, co oznacza spadek o $36 \%$ w stosunku do analogicznego okresu 2019 roku. Wolumen obrotu na rynku wtórnym akcji spadł o 62,3\% i wyniósł 203,6 mld tenge (Sprawozdanie roczne KASE, 2020). Tak znaczący spadek wynika z posiadania w 2019 r. dużej ilości transakcji 
o nieregularnym charakterze na rynku wtórnym, spowodowanych zmianą akcjonariuszy kilku spółek oraz odkupem akcji SA «Eksploracja i wydobycie KazMunaiGaz». Największe spadki cen w 2019 r. odnotowano na akcjach - SA «KazakhTelekom» $(-19,1 \%)$ i SA «KazTransOil» $(-22,8 \%)$. Dynamikę notowań składników indeksu KASE można zobaczyć na wykresie 2.

Rozwój rynku papierów wartościowych wiąże się z koniecznością określenia kluczowego ryzyka wpływającego na dynamikę ceny akcji (a tym samym na wartość spółki jako całości), co ujawni dywersyfikacyjny potencjał inwestowania w kazachskie spółki w ramach zarówno kazachskiego rynku akcji, jak i globalnego portfela inwestycyjnego inwestorów międzynarodowych.

Z uwzględnieniem powyższych przesłanek sformułowano następującą hipotezę badawczą: ceny akcji spółek kazachstanskich notowanych na KASE silne zależą od zmian cen ropy naftowej na giełdach światowych. Weryfikacja przyjętej hipotezy badawczej oraz realizacja określonego w pracy celu wymagała zastosowania następującej metodologii badawczej: studiów oraz krytycznej oceny literatury, zarówno krajowej, jak i zagranicznej z zakresu oceny determinantów wpływających na zmiany cen akcji spółek.

\section{PRÓBA BADAWCZA}

Na rynku kapitałowym Kazachstanu spółki z różnych branż gospodarki oferują różne instrumenty finansowe - akcje, obligacje, certyfikaty depozytowe. W publikacji oceniana będzie wartość akcji następujących kazachskich spółek:

SA «Bank CentrKredyt», który jest na liście pięciu największych banków komercyjnych w Kazachstanie. Bank posiada własną szeroką sieć oddziałów na terenie kraju, obsługuje osoby prawne i fizyczne w ponad 100 oddziałach. Sieć korespondencyjna banku ma około 40 zagranicznych banków, co pozwala na dokonywanie rozliczeń z partnerami na całym świecie.

SA «KazMinerals PLS», który jest jednym z największych przedsiębiorstw produkujących miedź w Kazachstanie. Spółka wykazuje jeden z najwyższych wskaźników wzrostu produkcji przy jednym z najniższych wskaźników kosztów produkcji wśród producentów miedzi na świecie. Od 2005 roku emituje GDR (Global Depositary Receiptna) na Londyńskiej Giełdzie Papierów wartościowych (London Stock Exchange - LSE).

SA «Halyk Bank» jest na liście pięciu największych banków komercyjnych w Kazachstanie. Na poziomie standardów międzynarodowych bank świadczy w Kazachstanie i kilku innych krajach usługi we wszystkich segmentach rynku finansowego (w bankowości, ubezpieczeniach, na rynku kapitałowym, usług leasingu). SA «Halyk Bank» ze względu na zysk netto jest drugim na liście banków 
Państw Niepodległych Krajów i pierwszym na liście wśród kazachskich przedsiębiorstw w całym kraju.

SA «Kcell» jest operatorem sieci komórkowej, świadczy usługi mobilnej komunikacji głosowej, krótkich wiadomości oraz usługi dodatkowe (VAS), takie jak wiadomości multimedialne, dostęp do treści mobilnych, a także usługi transmisji danych, w tym dostęp do Internetu. Od 2010 roku SA «Kcell» emituje GDR (Global DepositaryReceiptna) na Londyńskiej Giełdzie Papierów wartościowych (LSE).

SA «NAK KazAtomProm» to światowy lider w przemyśle nuklearnym i wiodący producent uranu na świecie. NAK KazAtomProm jest także krajowym operatorem kazachskiego importu-eksportu uranu, rzadkich metali, paliwa jądrowego, specjalnego sprzętu, technologii i materiałów do atomowej stacji elektroenergetycznej.

SA «KazakhTelekom» jest największym przedsiębiorstwem telekomunikacyjnym Kazachstanu i ma status krajowego operatora sieci telekomunikacyjnej. Spółka jest właścicielem krajowej super-autostrady informacyjnej, która jest transportowym pierścieniem światłowodowym łączącym cyfrowe strumienie o wysokiej szybkości transmisji danych do dużych miast Kazachstanu. Od 2000 roku SA «KazakhTelekom» emituje GDR (Global DepositaryReceiptna) Londyńskiej Giełdzie Papierów wartościowych (LSE). Od połowy 2000 roku stale zajmuje wysoką pozycję $\mathrm{w}$ rankingu najbardziej dochodowych przedsiębiorstw w kraju z rocznym obrotem w dziesiątkach miliardów tenge.

SA «KazTransOil» to jedno $\mathrm{z}$ największych przedsiębiorstw naftowo-gazowych w Kazachstanie, które zajmuje się usługami w zakresie transportu ropy naftowej oraz gazu na rynek wewnętrzny i zewnątrz. W rurociągu spółki płynie ropa do czarnomorskiego portu Noworosyjsk i dalej do Europy (Włochy, Holandia, Francja, Austria, Szwajcaria i inne), a także przez rurociąg Baku-Tbilisi-Geyhan do Turcji.

SA «KEGOC» (Kazakhstan Electricity Grid Operating Company) - głównym przedmiotem działalności jest świadczenie usług systemowych w zakresie transferu energii elektrycznej przez krajową sieć elektryczną. SA «KEGOC» jest jednym z pierwszych przedsiębiorstw które udanie wyemitowało swoje akcje w ramach Programu IPO (Initial Public Offering) w Kazachstanie.

Powodem wyboru do zbadania walorów tych spółek jest to, że akcje te są najbardziej płynne na rynku akcyjnym i są bardzo popularne wśród inwestorów jako instrumenty finansowe do inwestycji. 


\section{METODA WYCENY WARTOŚCI SPÓłEK}

W artykule badane są współzależności między zmianami światowych cen ropy naftowej a zmianami cen akcji spółek notowanych na giełdzie papierów wartościowych w Kazachstanie. W praktyce, w celu badania zależności między danymi, szczególnie w sposób liniowy, używany jest współczynnik korelacji.

Korelacja (współzależność cech) określa wzajemne powiązania pomiędzy wybranymi zmiennymi. Celem analizy korelacji jest stwierdzenie, czy między badanymi zmiennymi zachodzą jakieś zależności, jaka jest ich siła, jaka jest ich postać i kierunek. Współzależność między zmiennymi może być dwojakiego rodzaju: funkcyjna lub stochastyczna (probabilistyczna).

Istota zależności funkcyjnej polega na tym, że zmiana wartości jednej zmiennej powoduje ściśle określoną zmianę wartości drugiej zmiennej. W przypadku zależności funkcyjnej: określonej wartości jednej zmiennej $(\mathrm{X})$ odpowiada jedna i tylko jedna wartość drugiej zmiennej (Y).

Zależność probabilistyczna występuje wtedy, gdy wraz ze zmianą wartości jednej zmiennej zmienia się rozkład prawdopodobieństwa drugiej zmiennej. Szczególnym przypadkiem jest zależność korelacyjna, które polega na tym, że określonym wartościom jednej zmiennej odpowiadają ściśle określone średnie wartości drugiej zmiennej. Możemy wtedy ustalić, jak zmieni się - średnio biorąc - wartość zmiennej zależnej Y w zależności od wartości zmiennej niezależnej X. Wzór za pomocą którego oblicza się współczynnik korelacji ma postać (Trzpiot, 2020):

$$
r=\frac{\sum\left(x_{i}-\bar{x}\right)\left(y_{i}-\bar{y}\right)}{\sqrt{\sum\left(x_{i}-\bar{x}\right)^{2}} \sum\left(y_{i}-\bar{y}\right)^{2}}
$$

gdzie $x_{i}$ i $y_{i}$ oznaczają odpowiednio wartości zmiennych $x$ i $y$, a $\bar{x}$ i $\bar{y}$ średnie wartości tych zmiennych.

Siłą liniowego związku pomiędzy dwiema zmiennymi, jest współczynnik korelacji z próby $r$. Przyjmuje wartości z przedziału domkniętego $<-1 ; 1>$. Znak współczynnika $r$ mówi nam o kierunku zależności :

1) $r=0$, brak korelacji - brak związku między cechami;

2) $r<0$, korelacja ujemna - gdy wartości jednej cechy rosną, to wartości drugiej cechy maleją i odwrotnie;

3) $r>0$, korelacja dodatnia- gdy wartości jednej cechy rosną, to wartości drugiej cechy również rosną i odwrotnie. 
Wartosc bezwzględna współczynnika korelacji, czyli $r$, mówi nam o sile zależności. Jeżeli wartość bezwzględna $r$ :

- jest mniejsza od 0,2, to praktycznie brak związku liniowego pomiędzy badanymi cechami,

- 0,2-0,4 - zależność liniowa wyraźna, lecz niska,

- 0,4-0,7 - zależność liniowa umiarkowana,

- 0,7-0,9 - zależność liniowa znacząca, lecz wysoka,

- powyżej 0,9 - zależność liniowa bardzo silna.

Współczynnik korelacji $r$ (z próby) stanowi ocenę współczynnika korelacji $\rho$ $\mathrm{w}$ zbiorowości generalnej i w związku z tym jest obciążony pewnym błędem. Współczynnik korelacji jest statystyką, w związku z czym powinien być traktowany jako zmienna losowa. Jeśli zatem N-elementowa próba została pobrana ze zbiorowości generalnej o dwuwymiarowym rozkładzie normalnym z parametrem $\rho=0$, a więc gdy zmienne $\mathrm{X}$ i Y są nieskorelowane i zarazem niezależne, to zmienna losowa o postaci (Welfe, 2018):

$$
t=\frac{r}{\sqrt{\left(1-r^{2}\right)}} \times \sqrt{n-2}
$$

ma rozkład $t$ znaczenia o n-2 stopniach swobody.

W praktyce oznacza to, że formułujemy hipotezę zerową, czyli H0: $\rho=0$ i hipotezę alternatywną H1: $\rho \neq 0$, a następnie porównujemy wartość graniczną alfa z wartością obliczoną $t$ i podejmujemy odpowiednią decyzję odnośnie $\mathrm{H}$ 0.

Najpopularniejszymi rodzajami współczynników są współczynniki Pearsona i rang Spearmana. Aby określić, w jaki sposób zmiany cen ropy naftowej wpływają na zmiany cen akcji spółek notowanych na giełdzie papierów wartościowych w Kazachstanie obliczymy współczynniki korelacji Pearsona $-r_{x y}$. Współczynnik ten wykorzystywany jest do badania związków prostoliniowych badanych zmiennych, w których zwiększenie wartości jednej z cech powoduje proporcjonalne zmiany średnich wartości drugiej cechy (wzrost lub spadek). Współczynnik korelacji liniowej dwóch zmiennych jest ilorazem kowariancji i iloczynu odchyleń standardowych tych zmiennych, czyli współczynnik ten obliczamy na podstawie wzoru (Sagan, 2016):

$$
r_{x y}=\frac{\operatorname{cov}(x, y)}{S d_{x} \times S d_{y}}
$$


Kowariancja jest średnią arytmetyczną iloczynu odchyleń wartości zmiennych X i Y od ich średnich arytmetycznych:

$$
\operatorname{cov}(x, y)=\frac{\sum\left(x_{i}-\bar{x}\right)\left(y_{i}-\bar{y}\right)}{n}
$$

Kowariancja przyjmuje wartości liczbowe z przedziału: $[-\mathrm{s}(x) \mathrm{s}(y),+\mathrm{s} \mathrm{s}(x) \mathrm{s}(y)]$, gdzie $\mathrm{s}(x)$ i s $(y)$ są odchyleniami standardowymi odpowiednich zmiennych. Jeżeli $\operatorname{cov}(x, y)=-\mathrm{s}(x) \mathrm{s}(y)$, to między zmiennymi istnieje ujemny związek funkcyjny. Przy dodatnim związku funkcyjnym $\operatorname{cov}(x, y)=+\mathrm{s}(x) \mathrm{s}(y)$. Kowariancja charakteryzuje współzmienność badanych zmiennych, ale jej wartość zależy od rzędu wielkości, w jakich wyrażone są obydwie cechy, co powoduje, że nie można jej wykorzystać w sposób bezpośredni do porównań.

Współczynnik korelacji Pearsona często wykorzystują osoby inwestujące na rynkach akcji i obligacji. Pomaga między innymi przy dywersyfikacji portfela, która jest bardzo ważna, ponieważ obniża ryzyko.

\section{WYNIKI BADAŃ}

\section{Światowe ceny ropy naftowej i wartośc spółek Kazachstanu}

W ramach tego artykułu analizowany jest wpływ światowych cen ropy naftowej na kapitalizację. W tym celu przeprowadzono analizę regresji i korelacji wpływu dziennych notowań ropy naftowej na dzienne notowania akcji 8 spółek objętych obliczeniem indeksu KASE za okres od 1 stycznia 2012 r. do 1 stycznia 2020 r. Do analizy danych wybrana została ropa naftowa marki Brent. Wybór marki Brent jako czynnika wpływającego wynika z faktu, że marka ta jest głównym rodzajem ropy eksportowanej przez kazachskie spółki. Ponadto jest on wykorzystywany w obliczeniach wskaźników finansów publicznych. Jako czynniki charakteryzujące dynamikę kazachskiego rynku akcji wybrano akcje spółek uwzględnionych w obliczeniach indeksu KASE które generują 80\% obrotu na giełdzie i rzeczywiście determinują płynność rynku akcji (tabela 1).

Ponieważ rynek kapitałowy w pewnym stopniu odzwierciedla pozycję w realnej gospodarce kraju, należy założyć, że dynamika jego wskaźników jest skorelowana z dynamiką rozwoju kazachskiego rynku akcji.

Tak więc czynniki wpływające na rozwój gospodarki, z punktu widzenia oczekiwanych przyszłych przepływów, wpływają na kapitalizację spółek, której odzwierciedleniem są notowania rynkowe na rynku finansowym. Ponieważ Kazachstan jest krajem, który eksportuje głównie zasoby energii, zmiana cen ropy naftowej jest kluczowym czynnikiem ryzyka dla wielu kazachskich spółek. 
Tabela 1 Spółki wchodzące w skład indeksu KASE, ich kapitalizacja na dzień 1 stycznia 2020 r.

\begin{tabular}{|l|c|r|r|l|}
\hline \multicolumn{1}{|c|}{ Spółka } & Kod akcji & \multicolumn{1}{c|}{$\begin{array}{c}\text { Cena } \\
\text { akcji, } \\
\text { KZT }\end{array}$} & $\begin{array}{c}\text { Kapitalizacja, } \\
\text { KZT }\end{array}$ & \multicolumn{1}{c|}{ branża } \\
\hline $\begin{array}{l}\text { SA «Bank } \\
\text { CentrKredyt» }\end{array}$ & CCBN & 315,0 & 180000899 & Sektor finansowy \\
\hline SA «KazMinerals PLS» & GB_KZMS & 3521,0 & 480723977 & $\begin{array}{l}\text { Hutnictwo } \\
\text { i górnictwo }\end{array}$ \\
\hline SA «Halyk Bank» & HSBK & 123,0 & 11754049397 & Sektor finansowy \\
\hline SA «Kcell» & KCEL & 2780,0 & 200000000 & Telekomunikacja \\
\hline SA «KEGOC» & KEGOK & 1697,0 & 259998610 & Sektor energetyczny \\
\hline $\begin{array}{l}\text { SA «NAK } \\
\text { KazAtomProm» }\end{array}$ & KZAP & 7190,0 & 259356608 & Przemysł nuklearny \\
\hline SA «KazakhTelekom» & KZTK & 26685,0 & 10706027 & Telekomunikacja \\
\hline SA «KazTransOil» & KZTO & 1065,0 & 384628099 & $\begin{array}{l}\text { Sektor naftowy } \\
\text { i gazowy }\end{array}$ \\
\hline
\end{tabular}

Źródło: https://kase.kz/ru/stock_market/index_kase/

Aby udowodnić istnienie związku między ceną ropy naftowej a wartością spółek kazachskich, za pomocą współczynnika korelacji liniowej Pearsona obliczono modele regresji określające jej kształt i kierunek, w tym zmienną zależną Y (ceny akcji spółek objętych obliczeniem indeksu KASE) i zmienną X (codzienne notowania ropy naftowej na światowych giełdach). Te modele regresji są budowane na podstawie dziennych notowań za okres od 1 stycznia 2012 r. do 1 stycznia 2020 r. Ponadto, aby ocenić, jak dobrze modele regresji zależności notowań spółek od cen ropy naftowej odzwierciedlają rzeczywistą dynamikę notowań, obliczono współczynniki determinacji. Współczynnik determinacji określa procent całkowitej zmienności wielkości zależnej, wyjaśnionej przez niezależną wielkość zgodnie z równaniem regresji. Na przykład współczynnik determinacji wynoszący 0,79 pokazuje, że zmiany wielkości niezależnej wyjaśniają 79\% zmiany wielkości zależnej. Obliczone równania regresji i współczynniki determinacji przedstawiono w tabeli 2 .

Analiza współczynników determinacji pokazuje dość wysoką zdolność wyjaśniającą obliczonych równań regresji notowań spółek w zależności od cen ropy naftowej dla wszystkich gałęzi gospodarki. Tak więc, między kapitalizacją spółek reprezentowanych na kazachskim rynku akcji a ceną ropy naftowej zidentyfikowano trwałe powiązania, które można analizować statystycznie. Dane komunikacyjne istnieją niezależnie od branży badanej spółki. Oprócz tego istnieje dość wysoka statystycznie istotna korelacja między notowaniami spółek kazachskiego rynku akcji a notowaniami cen ropy naftowej, o czym świadczy analiza korelacji. Wynikiem tej analizy są obliczone współczynniki korelacji. Aby określić ścisłość 
połączenia, przeprowadzono ich analizę za pomocą skali Cheddocka. Na podstawie wyników analizy siły korelacji w gałęziach gospodarki zbudowana jest macierz (tabela 3).

Tabela 2. Zależność regresji między ceną akcji (Y) a ceną ropy naftowej na giełdach światowych (X)

\begin{tabular}{|l|l|l|c|}
\hline \multicolumn{1}{|c|}{ Spółka } & \multicolumn{1}{c|}{ Branża } & $\begin{array}{c}\text { Zależność ceny akcji od } \\
\text { cen zasobów energetycz- } \\
\text { nych }\end{array}$ & $\begin{array}{c}\text { Współczynnik } \\
\text { determinacji, } \%\end{array}$ \\
\hline SA «Bank CentrKredyt» & Sektor finansowy & $\mathrm{Y}=128,71+0,00676 \mathrm{X}$ & 71,96 \\
\hline SA «KazMinerals PLS» & Hutnictwo i górnictwo & $\mathrm{Y}=-817,9+0,14239 \mathrm{X}$ & 49,13 \\
\hline SA «Halyk Bank» & Sektor finansowy & $\mathrm{Y}=-36,01+0,00544 \mathrm{X}$ & 69,74 \\
\hline SA «Kcell» & Telekomunikacja & $\mathrm{Y}=612,88+0,06634 \mathrm{X}$ & 50,26 \\
\hline SA «KEGOC» & Sektor energetyczny & $\mathrm{Y}=-467,4+0,06953 \mathrm{X}$ & 79,20 \\
\hline $\begin{array}{l}\text { SA «NAK KazAtom- } \\
\text { Prom» }\end{array}$ & Przemysł nuklearny & $\mathrm{Y}=-694,3+0,46796 \mathrm{X}$ & 82,06 \\
\hline SA «KazakhTelekom» & Telekomunikacja & $\mathrm{Y}=-5135+1,2137 \mathrm{X}$ & 72,50 \\
\hline SA «KazTransOil» & $\begin{array}{l}\text { Sektor naftowy i ga- } \\
\text { zowy }\end{array}$ & $\mathrm{Y}=380,51+0,02706 \mathrm{X}$ & 65,10 \\
\hline
\end{tabular}

Źródło: obliczenia własne.

Tabela 3. Współczynniki korelacji między notowaniami spółek a cenami ropy naftowej rozłożonymi w skali Cheddocka

\begin{tabular}{|l|l|l|l|}
\hline \multicolumn{1}{|c|}{ Branża } & \multicolumn{1}{|c|}{$\begin{array}{c}\text { Bardzo wysoka } \\
\text { korelacja }\end{array}$} & \multicolumn{1}{|c|}{ Wysoka korelacja } & Zauważalna korelacja \\
\hline $\begin{array}{l}\text { Sektor naftowy i ga- } \\
\text { zowy }\end{array}$ & & $\begin{array}{l}\text { SA «KazTransOil» } \\
(0,80)\end{array}$ & \\
\hline Telekomunikacja & $\begin{array}{l}\text { SA «KazakhTelekom» } \\
(0,85)\end{array}$ & \\
\cline { 2 - 4 } & & & SA «Kcell» $(0,70)$ \\
\hline Przemysł nuklearny & $\begin{array}{l}\text { SA «NAK KazAtom- } \\
\text { Prom» }(0,90)\end{array}$ & & $\begin{array}{l}\text { SA «Bank CentrKre- } \\
\text { dyt» }(0,84)\end{array}$ \\
\hline Sektor finansowy & & $\begin{array}{l}\text { SA «Halyk Bank» } \\
(0,83)\end{array}$ & \\
\cline { 2 - 5 } & & & $\begin{array}{l}\text { SA «KazMinerals PLS» } \\
(0,70)\end{array}$ \\
\hline Sektor energetyczny & SA «KEGOC» $(0,89)$ & & \\
\hline Hutnictwo i górnictwo & & &
\end{tabular}

Źródło: obliczenia własne.

Jak widać z tabeli 3, wszystkie gałęzie gospodarki Kazachstanu reprezentowane na kazachskim rynku akcji mają wysoką korelację między ich kapitalizacją a ceną ropy naftowej. We wszystkich badanych przypadkach korelacja ta jest dodatnia, czyli wraz ze wzrostem ceny ropy naftowej wzrastają ceny akcji spółek 
notowanych na KASE i odwrotnie, przy spadku cen ropy na światowych giełdach ceny akcji spółek kazachskich spadają. Bardzo wysoką korelację mają spółki z gałęzi energetyki (SA «KEGOC») i przemysłu nuklearnego (SA «NAK KazAtomProm»), odpowiednio 0,89 i 0,90. Oprócz tego silnie jest zależna kapitalizacja spółek z sektora telekomunikacyjnego, finansowego i naftowo-gazowego od zmian cen ropy na światowych rynkach. Współzałeżność w tych gałęziach wynosi więcej niż 0,80 i to świadczy o tym, że ryzyko panujące w branży naftowej automatycznie przenosi się do tych branż.

Z praktycznego punktu widzenia, zidentyfikowane powiązania korelacyjne można wyjaśnić zarówno przyczynami ekonomicznymi, jak i psychologicznymi:

- Na podstawie analizy realnej gospodarki Kazachstanu (struktura PKB, dochody rządowe, eksport) i rynku finansowego (stan na 1 stucznia 2019 r.) udział SA «NAK KazAtomProm»w całkowitej kapitalizacji spółek uwzględnionych w obliczeniach indeksu KASE wyniósł 17,6\%, SA «KEGOC»-10,7\%, SA «KazTransOil» $-9,6 \%$, oczywiste jest, że przemysł energetyczny odgrywa w nim znaczącą rolę. Badanie ryzyka ich rozwoju i wpływu na inne gałęzie gospodarki ma kluczowe znaczenie dla zrozumienia funkcjonowania zarówno realnej gospodarki, jak i rynku akcji. Jednocześnie tak znacząca rola branż energetycznych może pośrednio wpływać na definicję kapitalizacji rynkowej spółek innych branż. Czynniki wewnętrzne - model gospodarki surowcowej, jej struktura (wysoki udział sektorów energetycznych) i finanse publiczne, w których główną rolę odgrywają dochody z ropy i gazu, prowadzą do znacznej zależności rynku akcji Kazachstanu od czynnika zewnętrznego - dynamiki cen ropy naftowej określonej przez globalny międzynarodowy poziom popytu i podaży na nie.

- Psychologicznie inwestorzy podlegający wpływowi ,nieracjonalnego zachowania" są skłonni do uproszczenia oceny konkretnego ryzyka i podkreślenia pewnego dominującego czynnika, przyczyniając się do nadania spekulacyjnego charakteru wycenie spółek na rynku akcji Kazachstanu.

W ten sposób przeprowadzona analiza wykazała, że zmiany cen ropy naftowej na rynkach światowych mają mocny wpływ na zmiany ceny akcji kazachskich spółek notowanych na KASE niezależnie od branży spółki. Skutkiem takiej zależności kazachskiego rynku akcji jest zmniejszenie jego atrakcyjności jako narzędzia dywersyfikacji portfela inwestycyjnego dla inwestorów krajowych i zewnętrznych.

\section{PODSUMOWANIE}

Sektor naftowy zajmuje wyjątkową pozycję w gospodarce Kazachstanu. Jednocześnie służy jako przewodnik po uzależnieniu gospodarki naszego kraju od stanu globalnej gospodarki, w tym kazachskiego rynku akcji od dynamiki globalnych cen ropy naftowej. Ryzyko panujące w branży naftowej przenosi się również na 
inne branże, stając się głównym elementem określającym stopień zmienności cen akcji, a co za tym idzie kapitalizację poszczególnych spółek i całego rynku. Celem tego artykułu jest zbadanie wpływu światowych cen ropy naftowej na notowania akcji wybranych spólek giełdowych w Kazachstanie. Wyniki badań wskazują, że przyjęta w artykule hipoteza okazała się prawdziwa: zmiana cen ropy naftowej na światowych rynkach ma bardzo mocny wpływ na zmianę cen akcji krajowych spółek Kazachstanu notowanych na KASE.

Skupienie się na akcjach spółek z listy indeksu KASE pozwoliło ocenić wpływ światowych cen ropy naftowej, które faktycznie generują największy obrót na giełdzie i rzeczywiście determinują płynność rynku. Przydałoby się zatem uzupełnić to badanie oceną wpływu światowych cen ropy naftowej na wartość wszystkich spółek kazachskich notowanych na Giełdzie Papierów Wartościowych Kazachstanu. Emitenci, profesjonalni uczestnicy rynku kapitałowego oraz inwestorzy mogą wykorzystywać wyniki tego badania przy dokonywaniu transakcji finansowych z papierami wartościowymi, a mianowicie z akcjami na KASE.

\section{BIBLIOGRAFIA}

Asness, C.S., Moskowitz T.J. and Pedersen L.H. (2013). Value and momentum everywhere. The Journal of Finance, 68(3), pp. 929-985.

Brayley, R. and Myers, S. (2008). Principles of corporate finance. Moscow: Press Olimp-Biznes.

Chordia, T., Subrahmanyam, A. and Anshuman, V.R. (2001). Trading Activity and Expected Stock Returns. Journal of Financial Economics, 59(1), 3-32, http://dx.doi.org/10.1016/ S0304405X(00)00080-5.

Copeland, T. and Koller, T. (2008). Valuation: Measuring and Managing the Value of Companies (Wiley Finance). Moscow: Press Olimp-Biznes.

Czerwińska, T. i Nowak, A.Z., red. (2016). Rynek kapitałowy - efektywność i ryzyko. Warszawa: Wydawnictwo Naukowe Wydziału Zarządzania Uniwersytetu Warszawskiego.

Fama E.F. and French K.R. (2008). Dissecting anomalies. Journal of Finance, 63, 1653-1678.

Sagan, A. (2016). Metodologia badań ekonomicznych. Kraków: Wydawnictwo Uniwersytetu Ekonomicznego.

Sprawozdanie roczne KASE, http://finreg.kz.

Trzpiot, G. (2020). Analiza danych z wykorzystaniem E-stat.me. Katowice: Wydawnistwo Uniwersytetu Ekonomicznego.

Ustawa Republiki Kazachstanu z dnia 13 maja 2003 r. nr 415-II o spółkach akcyjnych z późn. zm., www.online.zakon.kz

Ustawa Republiki Kazachstanu z dnia 2 lipca 2003 roku. o rynku papierów wartościowych i giełdzie, nr 461-II z późn. zm., www.online.zakon.kz

Welfe, A. (2018). Ekonometria. Warszawa: Wydawnictwo PWE. 